\title{
Effectivity of Augmented Reality as Media for History Learning
}

\author{
https://doi.org/10.3991/ijet.v14i16.10663 \\ Indah Wahyu Puji Utami ${ }^{(凶)}$, Ismail Lutfi \\ Slamet Sujud Purnawan Jati, Muhammad Yusuf Efendi \\ Universitas Negeri Malang, Malang, Indonesia \\ Indahwahyu.p.u@um.ac.id
}

\begin{abstract}
Augmented Reality (AR) as a learning media has a very great potential to help students learn history, including Indonesian ancient history. AR gave the opportunity for students to learn heritages from Indonesian's ancient history, i.e. from Singhasari period, by scanning a marker that would show $3 \mathrm{D}$ model in their smartphone screen. This research focusing on the effectivity of AR as media for history learning by comparing students' score in a pre-test post-test design. 30 students from 10th grade at a vocational high school involved in this quasi experiment. Overall, the AR is effective as history learning media in improving students' score.
\end{abstract}

Keywords-Augmented reality, media, history learning

\section{Introduction}

Combining real world with virtual reality, Augmented Reality (AR) has drawn attentions from educators and researchers worldwide. AR has been used as media in history learning worldwide, i.e. Schrier that developed AR for the battle of Lexington as part of American Revolution [1]. Her research found that AR could increase student's motivation in learning. It is one of other great potential of AR in learning as showed by other research. Coimbra, Cordoso \& Mateur stated that AR could increase student's comprehensive knowledge on the subject matter and its context so that the use of information, knowledge and digital literation increase as well [2]. Students could also learn independently or colaboratively by using AR inside and outside their classroom [3]. Therefore, AR could be use as media for history learning, including in ancient Indonesian history.

Back to ancients time in Indonesia $\left(5^{\text {th }}-16^{\text {th }}\right.$ century), there are a lot of Hindu kingdoms in this area. One of the important kingdom was Singhasari located in the area that know as Malang today. Founded by Ken Angrok in 1222, Singhasari soon became a great kingdom in Java and succed in expanding its territory. Despite its successful, this kingdom only last for 70 years and fall in the reign of its greatest king, Kertanegara, by a coup of Jayakatwang, a duke of Kadiri, in 1292.

Singhasari left many heritages in Malang, i.e. Candi Kidal, Candi Jago and Candi Singosari, that still exist nowadays [4]. Candi is a temple that use for worshiping the 
Gods and pendharmaan (deificating) a king. Candi Kidal is a deification temple for King Anusapati (ruled 1227-1248), Candi Jago is a deification temple for Wișnuwardhana (ruled 1254-1268) [5], while Candi Singosari is a deification temple for King Kertanegara (ruled 1268-1292).

Candi Kidal and Candi Jago are decorated with reliefs. There are two types of reliefs in those temples, decorative reliefs and story reliefs. While decorative reliefs only have decorative function to make the temples beautiful, the story reliefs have certain stories. Those stories usually inspired by Hindu's myth i.e. Mahabharata and Ramayana.

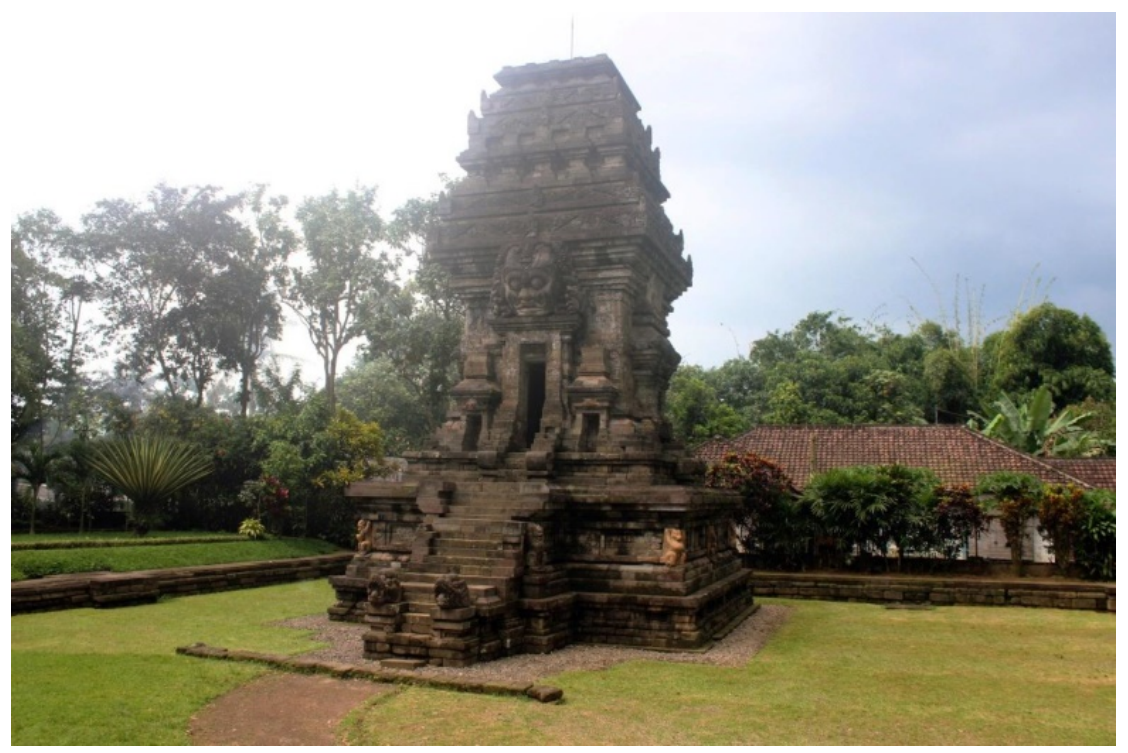

Fig. 1. Candi Kidal

Candi Kidal, located in eastern part of Malang, deocarted with story relief titlled Garudeya from Adiparwa Mahabarata (the book of beginning of Mahabarata) [6]. There are three Graudeya relief panels in Candi Kidal. The reliefs sclupted in its notth, east, and south sides. At the first panel, sclupted in north side, Garuda (the main character of the story, a creature on Hindu myth that has a mix of human and eagle features) is carriying his mother namely Winata. Winata told his son that she lost on a bet with her sister Kadru so that she must become Kadru's slave. Winata must taking care of Kadru's children (100 of sherpents) and must obey them [7]. At the second panel, sculptured in east side, Garuda is carrying sherpents. Garuda is helping his mother to take care of Kadru's children. The third panel, sculpted in south side, depicts Garuda carriying tirta amertha (exilir of life) above his head. The relief is about the success of Garuda on getting the exilir of life from the Gods. Garuda needs that exilir of life to release his mother from slavery by Kadru [7] [6]. 


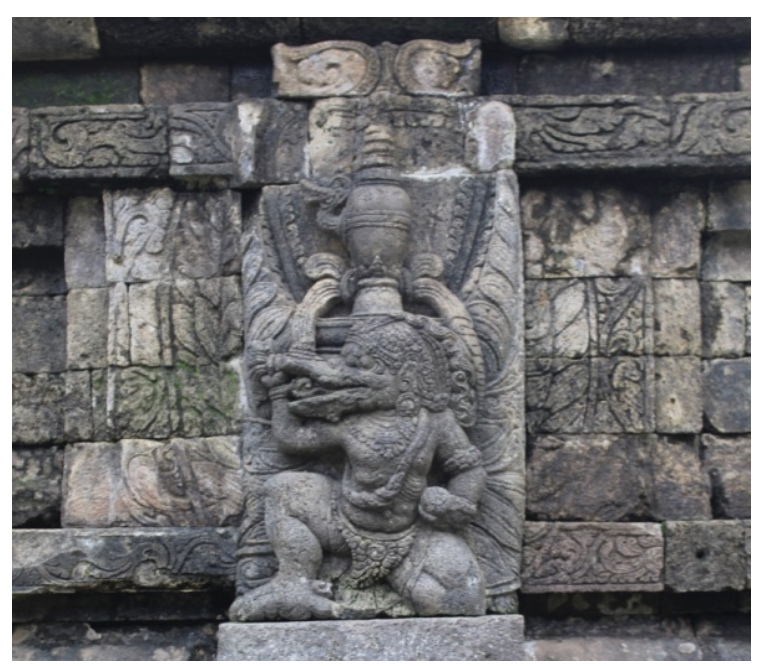

Fig. 2. A panel of Garudeya relief depicting Garuda carrying exilir of life

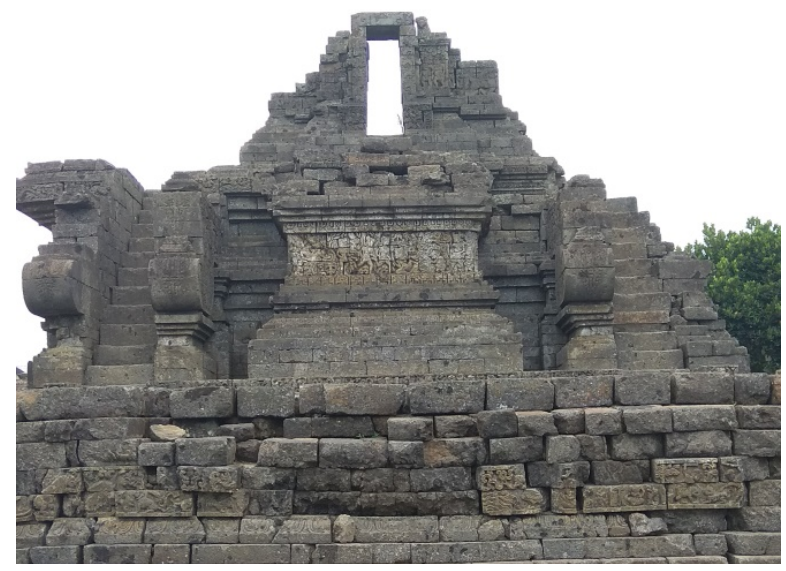

Fig. 3. Candi Jago

Located approximately 5 miles from Candi Kidal, Candi Jago decorated by more reliefs than Candi Kidal. According to Kieven [8] Candi Jago used not only by Hindu people but also by Budhist people so that it has a lot of reliefs from both religions. There are at least five story reliefs in this temple, namely Tantri Kamandaka, Ari Dharma, Kunjarakarna, Parthayajna or Arjunawiwaha, and Kresnayana [9]. Tantri Kamandaka in Candi Jago consist of eleven fable stories, i.e. the story of goose and two turtles. Ari Darma relief inspired by Serat Angling Darma about Ari Darma with dragons and sherpent. Kunjarakarna inspired by Kakawin Kunjarakarna about Kunjarakarna who learn about dharma and see what happen in the hell as well as heaven. Parthayajna relates with Mahabharata story. It tells about the journey of Partha (Arju- 
na) to Mount Indrakila to get a weapon for defeating Kurawa. The last relief is Kresnayana telling the story of the wedding of Kresna (a figure on the Mahabharata story) with Rukmini.

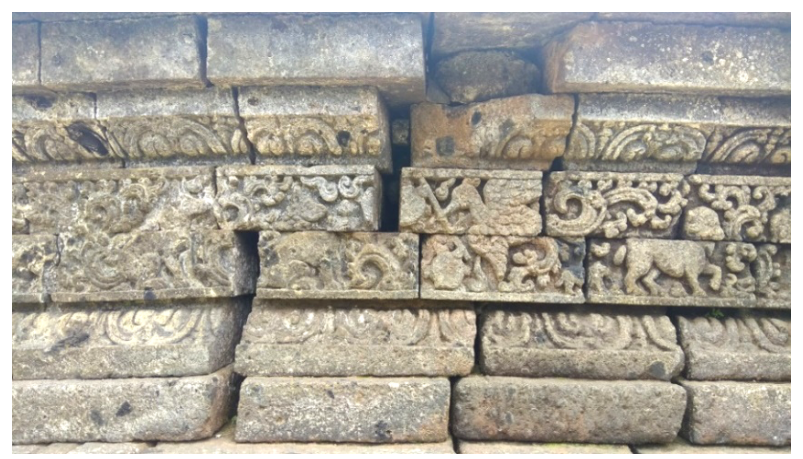

Fig. 4. A relief of Tantri Kamandaka about goose and turtles

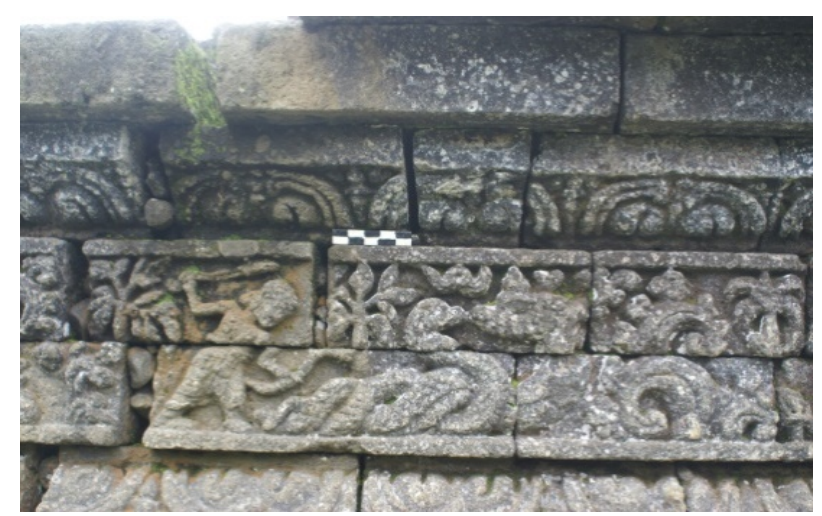

Fig. 5. Relief of Ari Darma

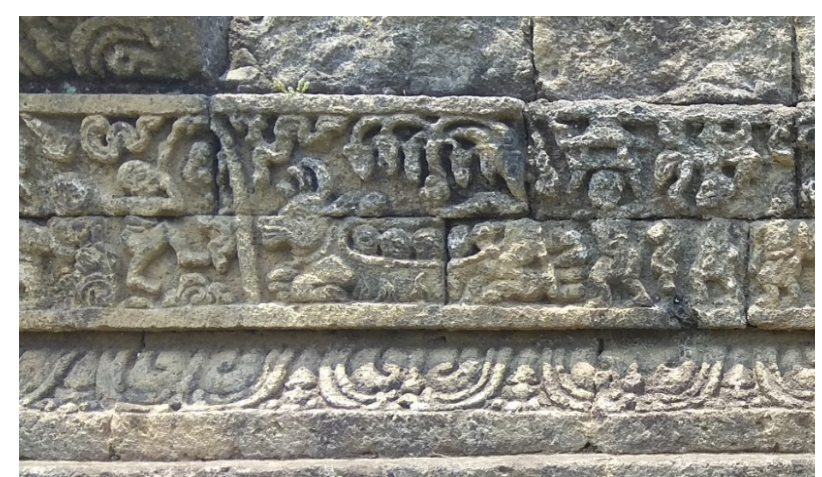

Fig. 6. A relief of Parthayajna 


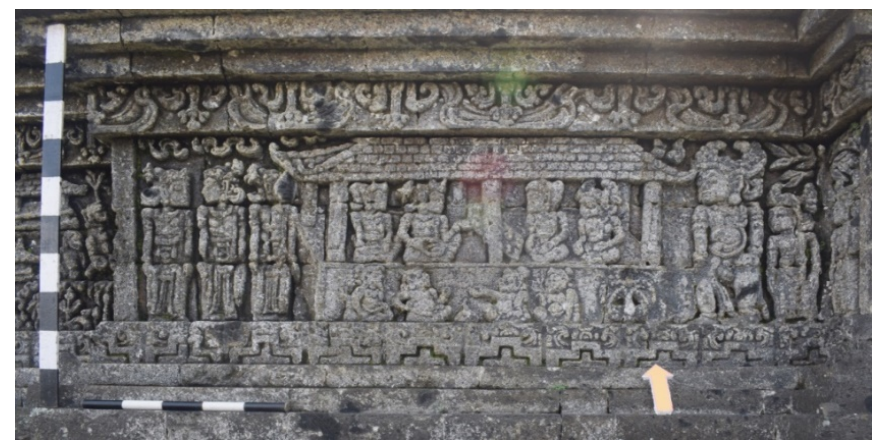

Fig. 7. A relief of Kunjarakarna

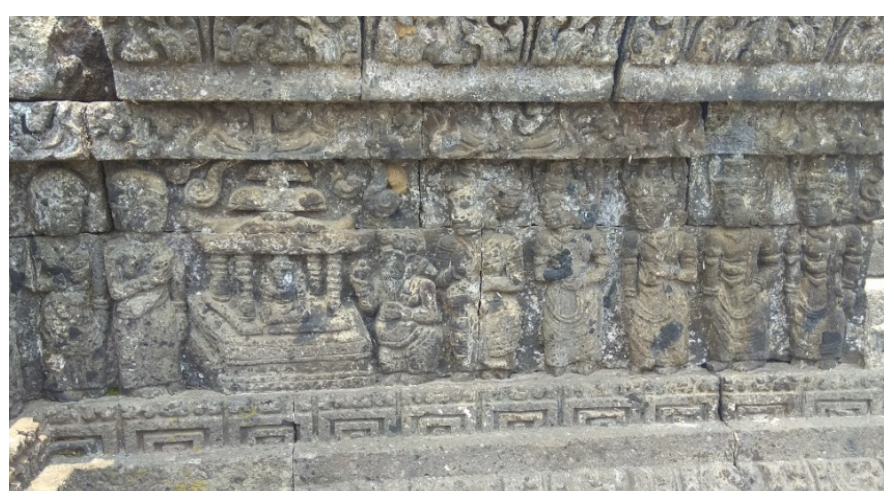

Fig. 8. A relief of Arjunawiwaha

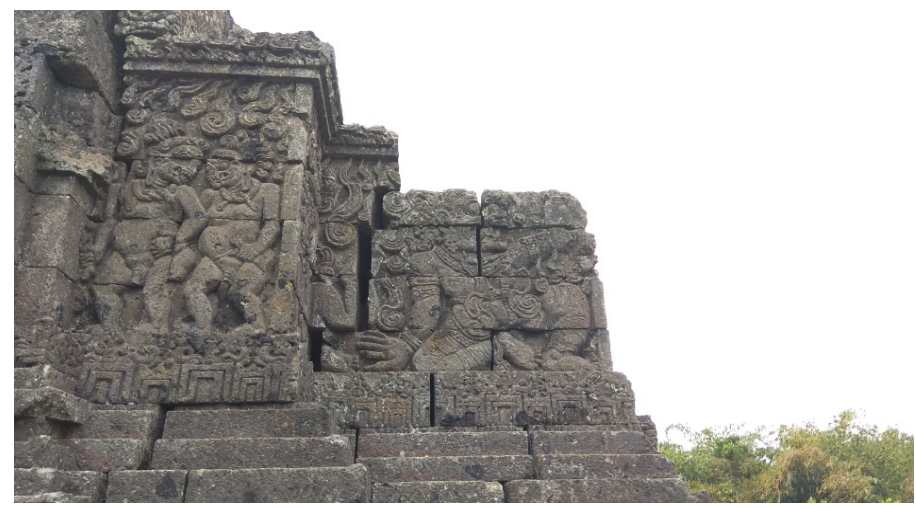

Fig. 9. A relief of Kresnayana 


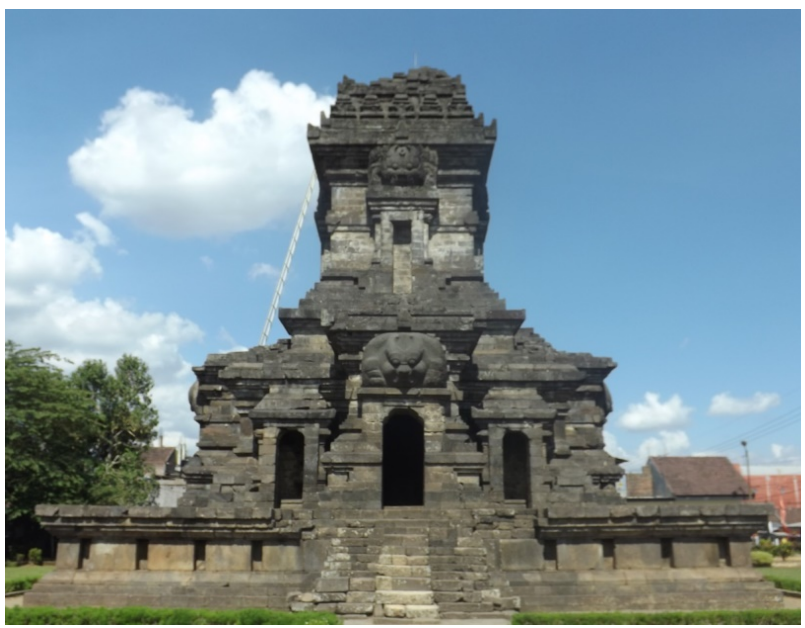

Fig. 10.Candi Singosari

Unlike two other temples mentioned before, Candi Singosari has no story relief. This temple lies on the northern side of Malang and built as deification site for Kertanegara, the last king of Singhasari. It is estimated that this temple is not yet completed and left because the kingdom was attacked by Jayakatwang. However, among the Singhasari heritage in Malang, this temple is relatively intact.

Those temples could be use as valuable sources for history learning. However, the location of those temples are scattered around Malang so that it is not easy for students to reach this sites. Therefore, we want to juxtapose the heritages with students by developing AR.

AR could shows 3D model on temples and reliefs by scanning on markers using a certain aplication. Card as markers are easy to bring and being use in learning process. While the aplication could be shared easily with student's smartphone. Therefore, AR could be a very interesting media for history learning.

This interesting media is required in history learning because there is a negative image on history learning in Indonesia. History seen as a dull and unimportant subject by students [10]. By using AR as an emerging media, students would be interesting in history learning. AR technology is able to help students to make it easier to visualize a historical event or historical heritage. The connection in this regard is a historical heritage in the form of temples and reliefs in 3D that are closer to the originals and students will be able to observe the details of the parts of the temple and the reliefs. The 3D model on AR would make students learn history in an easy and fun way.

Technology of AR combines virtual world with reality synchronously. This allows users to understand something more real. AR is the incorporation of real and virtual objects in the real environment, running interactively in real time. There is integration between objects in three dimensions, namely virtual objects integrated in the real world [11]. According to Rusnandi AR is a technology that combines twodimensional (2D) or three-dimensional (3D) objects into the real world and then projects virtual objects virtually [12]. 
There are three principles in AR.

- First, AR is a combination of the real and virtual world.

- Second, it runs interactively in real time.

- Third, there is integration between objects in 3D, namely virtual objects integrated in the real world [13].

A smartphone camera or webcam needed in the AR application to capture marker images. Once a marker is detected a 3D object will appear.

In its application, AR technology has several main components that must exist to support the performance of the use process. The components are as follows [14]:

a) Scene generator: Scene Generator is a component that has the task of rendering images captured by the camera. Virtual objects will be captured and then processed so that the object can be displayed.

b) Tracking system: Tracking system is the most important component in AR. In the tracking process, a real object pattern is detected with a real object so that it is synchronized between the two.

c) Display: There are several basic parameters that need to be considered in the development of AR technology, namely the factors of resolution, flexibility, point of view, and tracking area. On the tracking area the lighting factor becomes a matter that needs to be considered because it can affect the imaging process. In addition, the screen resolution can affect the image between virtual objects and real objects.

d) AR devices: There are several devices that can be used on AR devices such as smartphones and tablets. Nowadays, several applications with this technology are available on iPhone, iPad and Android. In addition, AR can be used on PCs that are already connected to a camera such as a webcam.

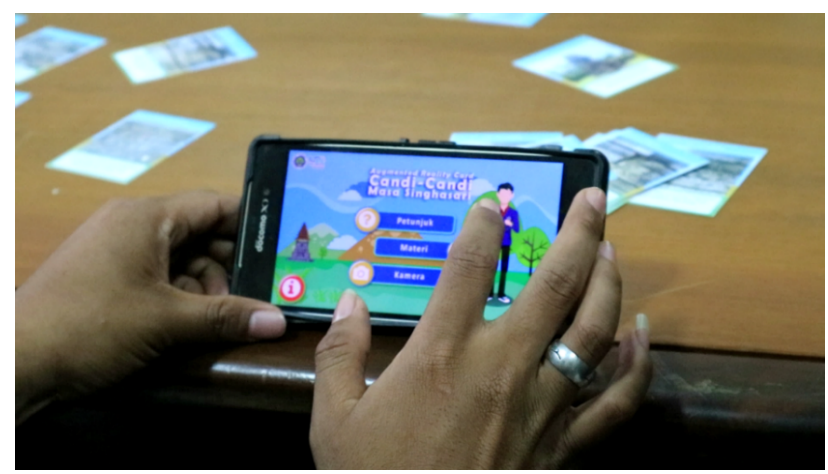

Fig. 11.The interface of Arc

In addition to the main components mentioned above, there are also supporting components to develop AR on an Android smartphone. The supporting components are Vuforia qualcomm or Vuvoria SDK. Vuforia Qualcomm is an Augmented Reality Software Development Kit (SDK) that enables the creation and development of AR applications on smartphones. Vuvoria detects images using marker detectors and 
produces information in the form of 3D illustrations of markers that have been detected via the Application Programming Interfaces in real-time. Vuvoria SDK also supports $2 \mathrm{D}$ and $3 \mathrm{D}$ target types including "markeless" image targets, besides that Vuvoria also provides APIs in C ++, Java, and Objective-C [15].

AR technology can be used as media for historical learning to assist teachers in depicting 3D model of reliefs, Candi Kidal, Jago and Singosari objects. We developed AR for Hindu's heritage in the Singhasari tittled Arc as media in learning history of Singhasari and its heritage [16]. In this research, we are focussing on the effectivity of Arc as history learning media to increase students' score.

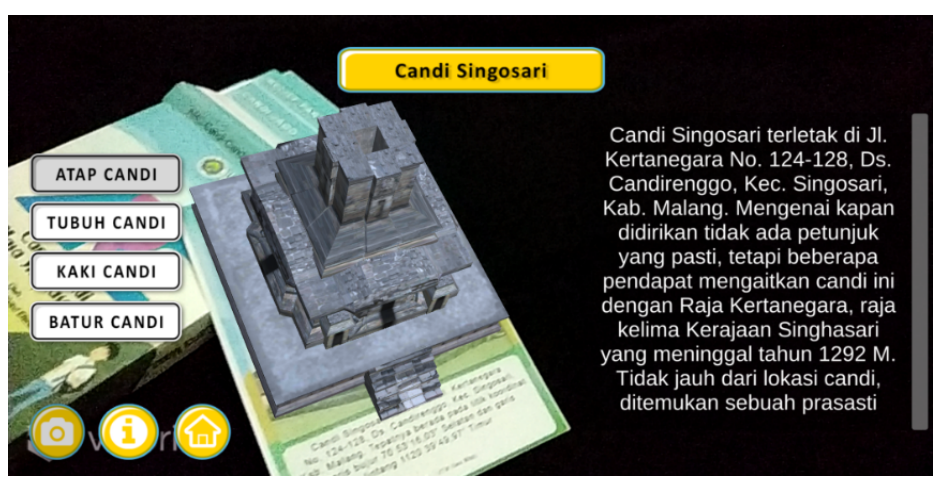

Fig. 12.An Example of 3D model shows in Arc

\section{$2 \quad$ Method}

The subject on this research are 30 students from $10^{\text {th }}$ grade Vacational Highschool 11 Malang. The study of efectivity of Arc as history learning media to increase students' score in this research used one-group pretest-posttest design. There are three steps, namely

1. Pretest

2. Intervention by application of Arc as media in history learning

3. Posttest.

Students were given pretest and asked to do it. Then, they were given the markers and apk file of Arc to be installed on their smartphone. They were asked to learn about the heritage of Singhasari by using this media. After that, they must do the post test. We compare students' grade on their pretest and posttest.

Data was test for its normality. Researcher would use dependent t-test should the data normal, otherwise we use Wilcoxon. We also use N-Gain score to see how much the difference of the pretest and post test to see the effectivity of Arc as history learning media. We refer the N-Gain classification from Archambault [17] (see table 1). 
Table 1. N-Gain Classification

\begin{tabular}{|l|l|}
\hline \multicolumn{1}{|c|}{ Percentage } & \multicolumn{1}{c|}{ Classification } \\
\hline $\mathrm{N}-$ Gain $>70$ & High \\
\hline $30 \leq \mathrm{N}-$ Gain $\geq 70$ & Average \\
\hline $\mathrm{N}-$ Gain $<70$ & Low \\
\hline
\end{tabular}

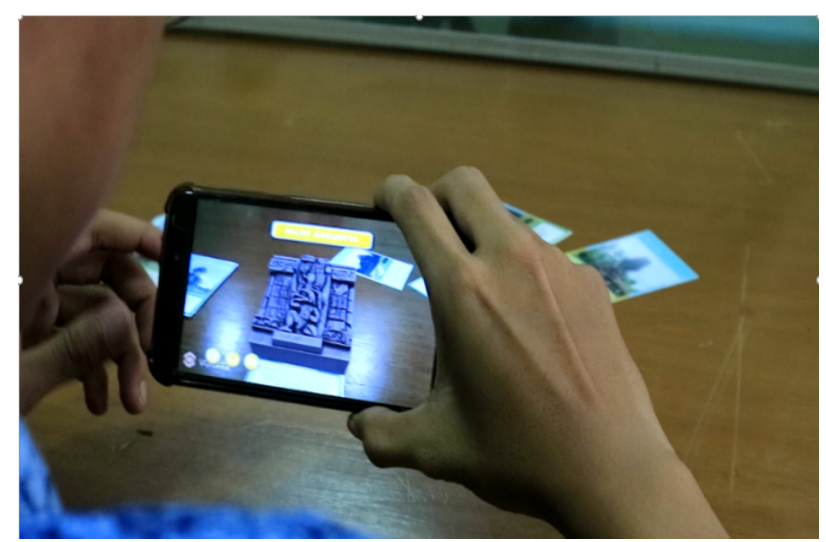

Fig. 13.3D model shows up on student's smartphone screen

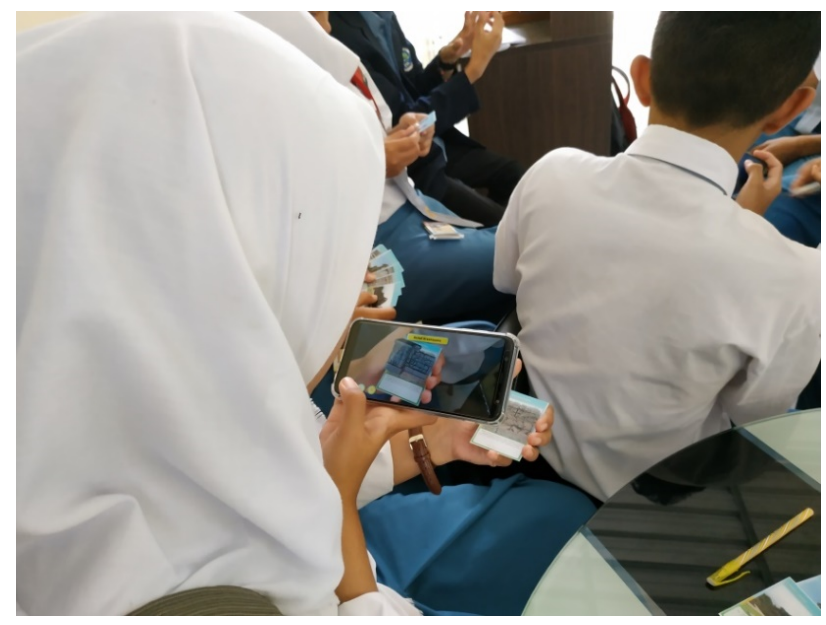

Fig. 14.Students use Arc Candi Masa Singhasari on history learning

\section{$3 \quad$ Results}

Data on this research collected from the test done by the students. The test is available in the application that run-in students' smartphone. Students need to open the application and do the test and the score automatically sent to the researchers. Based on the data of pre test and post test, we run the normality test to the data. Considering that $\mathrm{N}<50$, we refer to Shaphiro-Wilk normality data test. Based on table 2, the pre 
test sig. 0.000 which is less than 0.005 that means the data is not normal. The post test sig. 0.009 which is more than 0.005 that means the data is normal. Therefore, we use cannot run dependent t-test and run Wilcoxon test.

Table 2. The Tests of Normality

\begin{tabular}{|l|c|c|c|c|c|c|}
\hline & \multicolumn{3}{|c|}{ Kolmogorov-Smirnov } & \multicolumn{3}{c|}{ Shapiro-Wilk } \\
\cline { 2 - 7 } & Statistic & $\boldsymbol{d} \boldsymbol{f}$ & Sig. & Statistic & $\boldsymbol{d f}$ & Sig. \\
\hline Pretest & .264 & 30 & .000 & .800 & 30 & .000 \\
\hline Posttest & .235 & 30 & .000 & .902 & 30 & .009 \\
\hline
\end{tabular}

Lilliefors Significance Correction

Table 3. Wilcoxon Test Result

\section{Wilcoxon Signed Ranks Test}

\begin{tabular}{|c|c|c|c|c|}
\hline \multicolumn{5}{|c|}{ Ranks } \\
\hline & & $\mathrm{N}$ & Mean Rank & $\begin{array}{c}\text { Sum of } \\
\text { Ranks }\end{array}$ \\
\hline \multirow[t]{4}{*}{ posttest-Pretest } & Negative Ranks & $0^{a}$ & .00 & .00 \\
\hline & Positive Ranks & $30^{\mathrm{b}}$ & 15.50 & 465.00 \\
\hline & Ties & $0^{c}$ & & \\
\hline & Total & 30 & & \\
\hline
\end{tabular}

\footnotetext{
a. posttest $<$ Pretest

b. posttest $>$ Pretest

c. posttest $=$ Pretest
}

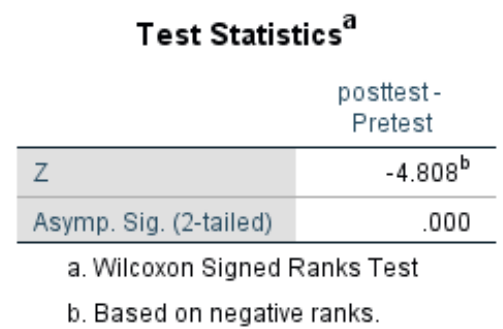

Based on table 3, the asymp. Sig. (2-tailed) 0.000 which is lower than 0.05 . Therefore, there is difference between pretest and posttest. There is also no decrease on all of students' score (see negative ranks on table 3), otherwise all of students' score are increase (see positive ranks on table 3) which also means that there is no student that has the same pretest and post test score. In order to see the effectivity of Arc as history learning media, we run $\mathrm{N}$-Gain test.

Based on table 4, the N-Gain average is 67.71427. It means that the effectivity of Arc as history learning media to increase students' score is average. 
Table 4. N-Gain Test Results

\begin{tabular}{|c|c|c|c|c|}
\hline No & Pre test & Post Test & N-Gain Score & N-Gain Percentage \\
\hline 1 & 40 & 70 & 0.5 & 50 \\
\hline 2 & 40 & 80 & 0.67 & 66.67 \\
\hline 3 & 40 & 60 & 0.33 & 33.33 \\
\hline 4 & 20 & 100 & 1 & 100 \\
\hline 5 & 20 & 70 & 0.63 & 62.5 \\
\hline 6 & 40 & 90 & 0.83 & 83.33 \\
\hline 7 & 40 & 80 & 0.67 & 66.67 \\
\hline 8 & 20 & 90 & 0.88 & 87.5 \\
\hline 9 & 40 & 60 & 0.33 & 33.33 \\
\hline 10 & 40 & 60 & 0.33 & 33.33 \\
\hline 11 & 40 & 80 & 0.67 & 66.67 \\
\hline 12 & 20 & 70 & 0.63 & 62.5 \\
\hline 13 & 20 & 90 & 0.88 & 87.5 \\
\hline 14 & 40 & 80 & 0.67 & 66.67 \\
\hline 15 & 30 & 80 & 0.71 & 71.43 \\
\hline 16 & 20 & 70 & 0.63 & 62.5 \\
\hline 17 & 40 & 80 & 0.67 & 66.67 \\
\hline 18 & 20 & 80 & 0.75 & 75 \\
\hline 19 & 20 & 80 & 0.75 & 75 \\
\hline 20 & 50 & 90 & 0.8 & 80 \\
\hline 21 & 20 & 70 & 0.63 & 62.5 \\
\hline 22 & 20 & 80 & 0.75 & 75 \\
\hline 23 & 30 & 80 & 0.71 & 71.43 \\
\hline 24 & 30 & 80 & 0.71 & 71.43 \\
\hline 25 & 40 & 70 & 0.5 & 50 \\
\hline 26 & 20 & 80 & 0.75 & 75 \\
\hline 27 & 20 & 80 & 0.75 & 75 \\
\hline 28 & 40 & 100 & 1 & 100 \\
\hline 29 & 30 & 80 & 0.71 & 71.43 \\
\hline 30 & 50 & 70 & 0.4 & 40.00 \\
\hline \multicolumn{4}{|l|}{ Mean } & 67.1427 \\
\hline \multicolumn{4}{|l|}{ Min } & 33.33 \\
\hline \multicolumn{4}{|l|}{ Max } & 100 \\
\hline
\end{tabular}

\section{Discussion}

Arc, as history learning media, certainly effects students score on learning history. There is difference before and after the treatment of using Arc as history learning media. The results of this research confirm Coimbra, Cardoso and Mateur research that AR could increase students' knowledge or learning achievement $[2,18]$.

The increasing of students' knowledge by using Arc as history learning media because AR technology due to several reasons as follows:

a) Students could repeat scan the marker to show $3 \mathrm{D}$ objects. This repetion could add clarity by students. This is because AR technology has implicit user control of the 
point of view and interactivity [19]. Students could control their smartphone to see from various point of view so that it can add clarity to the subject matter, namely the Hindu's heritages of Singhasari era.

b) By using 3D objects, AR enables students to augment the visual perception of the target system or environment [20]. 3D object on Arc could clarify abstract concepts by giving real examples, i.e. the concept of architectural part of Candi (roof, body, and base).

c) Arc could overcome distance and time limitations in history learning. The Hindu's heritages of Singhasari era are scattered around Malang, Indonesia. It needs a lot of time to visit all of them, while the Indonesian history only taught three hours a week in vocational high school.

d) The message delivered quickly and easily remembered by students. Arc as learning media can convey material messages more quickly due to the efficiency of learning time than students must learn in the classroom without the help of Arc as learning media.

Inspite of its ability to help students learn, Arc as learning media has several constraints in its application of history learning. The constraints are related with the technology and the device. First constrain that relates to the AR technology is that the Arc application is big in its size, namely $63 \mathrm{MB}$, due to a lot of 3D objects incorporating in this application. The first issue affected to the second issue, the device. Due to its big application size, students must have a device (smartphone) that can handle it. It also requires certain time to install the Arc application in students' device. Furthermore, to show a 3D object from a marker, students' device must have a good camera, otherwise it cannot read the markers. Students' might felt overwhelmed and confused because they had to deal with unfamiliar technologies [20]. Therefore, even though students' score is increased, but the increasing level is just in average level (see table 1 and table 4).

\section{Conclusion}

Bridging the virtual reality with real life, AR has drawn many attentions from educators. Many educator or researchers have been developing AR as learning media. We developed Arc as media for history learning, especially on the subject of Hindu's heritage of Singhasari era and tested for its effectivity. Based on our research, there is difference of students' score before and after using Arc on history learning. Students' score is increased in average level. Therefore, AR is effective as media in history learning. However, AR still have some issues in its application. Further research could be done to overcome those issues, i.e. on the technological issues or learning issues. Teacher's and students' responses on AR also need to be investigated in further research. 


\section{$6 \quad$ References}

[1] K. L. Schrier, "Revolutionizing History Education: Using Augmented Reality Games to Teach Histories," Massachusetts Institute of Technology, Massachusetts, 2005.

[2] T. Coimbra, T. Cardoso and A. Mateur, "Augmented Reality: An Enhancer for Higher Education in Math's Learning?" in 6th International Conference on Software development and Technology for enhancing Accessibility and Fighting Infoexclussion, 2006.

[3] J. Martin-Gutierez, P. Fabiani, W. Bonesova and M. D. Meneses, "Augmented Reality to Promote Collaborative and Autonomous Learning in Higher Education," Computer in Human Behavior, pp. 752-761, 2015. https://doi.org/10.1016/j.chb.2014.11.093

[4] A. A. Munandar, Catuspatha Arkeologi Majapahit, Jakarta: Wedatama. Widya Sastra, 2011.

[5] Soekmono, Candi: Fungsi dan Pemaknaannya, Jakarta, 2005

[6] N. Turaeni, "Aplikasi Adi Parwa dalam Relief Situs Candi Kidal," Forum Arkeologi, vol. 28, no. 2, pp. 131-144, 2015. https://doi.org/10.24832/fa.v28i2.27

[7] P. Scheurleer, "The Javanese Statue of Garuda Carrying Wisnu and Candi Kidal," Artibus Asiae, vol. 69, no. 1, pp. 189-218, 2009.

[8] L. Kieven, Menelusuri Figur Bertopi dalam Relief Candi Majapahit: Pandangan Baru terhadap Fungsi Religious Candi-candi Period Jawa Timur Abad ke-14 dan ke-15, Jakarta: KPG dan EFEO, 2017.

[9] B. Suprapta, D. N. Wijaya and U. Nafi'ah, Nilai-nilai Pendidikan Karakter dalam Relief Cerita Tantri, Yogyakarta: Penerbit Kanisius, 2017.

[10] J. Sayono, "Pembelajaran Sejarah di Sekolah: dari Pragmatis ke Idealis," Sejarah dan Budaya: Jurnal Sejarah, Budaya, dan Pengajarannya, pp. 9-17, 2013

[11] A. Idrus and Y. Ardeo, "Pengembangan Augmented Reality sebagai Media dalam Menigkatkan Pemahaman Teks Bacaan," Jurnal technology Pendidikan, vol. 18, no. 3, pp. 140-155, 2016. https://doi.org/10.21009/JTP1803.3

[12] E. Rusnandi, H. Sujadi and E. Fauzyah, "Implementasi Augmented Reality (AR) pada Pengembangan Media Pembelajaran Pemodelan Bangun Ruang 3D untuk Peserta Didi Sekolah Dasar," Infotech Journal, vol. 1, no. 2, pp. 24-31, 2016.

[13] J. Sahertian and Muladi, "Pengembangan Media Pembelajaran Berbasis Technology Augmented reality pada Pokok Bahasan Sel," Tekno, vol. 19, no. 1, pp. 9-14, 2013

[14] R. Silva, J. Oliveria and G. Giraldi, Introduction to Augmented reality, Brazil: National Laboratory for Scientific Computation, 2003.

[15] T. Suryanto, U. Ema and A. Hanif, "Rancang Bangun Virtual Gamelan Mobile Menggunakan Augmented Reality," Jurnal Dasi, vol. 15, no. 1, pp. 36-47, 2014.

[16] M. Y. Efendi, I. Lutfi, I. W. P. Utami and S. S. P. Jati, "Pengembangan Media Pembelajaran Sejarah Augmented Reality Card (Arc) Candi-candi Masa Singhasari Berbasis Unity 3D pada Pokok Materi Peninggalan Kerajaan Singhasari untuk Peserta Didik Kelas X KPR1 SMK Negeri 11 Malang," Jurnal Pendidikan Sejarah Indonesia, vol. 1, no. 2, pp. 176-187, 2018.

[17] J. Archambault, "The Effect of Developing Kinematics Concepts Graphically Prior to Introducing Algebric Problem Solving Techniques," Arizona State University, Arizona, 2008.

[18] M. Akcayir and G. Akcayir, " Advantages and challanges associated with augmented reality for education: a systematic review of the literature," Educational Research Review, vol. 201, no. 1, pp. 1-11, 2017. https://doi.org/10.1016/j.edurev.2016.11.002

[19] M. Kesim and Y. Ozarslan, "Augmented reality in education: current technologies and the potential for education," Procedia-Social and Behavioral Sciences, vol. 47, pp. 297-302, 2012. https://doi.org/10.1016/j.sbspro.2012.06.654

[20] H.-K. Wu, S. W.-Y. Lee, H.-Y. Chang and J.-C. Liang, "Current status, opportunities and challanges of augmented reality in education," Computers \& Education, vol. 62, pp. 41-49, 2013. https://doi.org/10.1016/j.compedu.2012.10.024 


\section{Authors}

Indah Wahyu Puji Utami is a lecturer on History Department, Faculty of Social Sciences, Universitas Negeri Malang. She is interested in social history, the intersection of technology and history education as well as curriculum and history textbooks.

Ismail Lutfi is a lecturer on History Department, Faculty of Social Sciences, Universitas Negeri Malang. He is a chair of East Java Archeological Association. He is interested in ancient Javanese ancient history.

Slamet Sujud Purnawan Jati is a lecturer on History Department, Faculty of Social Sciences, Universitas Negeri Malang. He is a chair of Centre of Pancasila Studies. $\mathrm{He}$ is interested on cultural history, prehistoric and ancient Javanese archeology.

Muhammad Yusuf Efendi is a staff on Learning Museum of Universitas Negeri Malang. He is majoring history education and interested in developing AR for history education.

Article submitted 2019-04-15. Resubmitted 2019-07-03. Final acceptance 2019-07-05. Final version published as submitted by the authors. 